\title{
Determination of the Time-Dependent Strength of Soil Stabilization with Rubber Particles
}

\author{
Baki Bagriacik \\ ${ }^{1}$ Çukurova University, Civil Engineering Deparment, Balcalı, Sarıçam, Adana 01330, Turkey
}

\begin{abstract}
Soil stabilizations are important in dealing with for geotechnical engineering and transportation engineering departments. There are a lot of stabilization methods. One of the most important soil stabilization method is the stabilization of the soils with materials such as lime, fly ash, glass fiber and rubber particles. In this study, serious tests have been conducted in the laboratory to determine the time-dependent (1 hour, 1 day, 7 day) unconfined compression strength of soil stabilization with rubber particles. Soil samples have been prepared at optimum water content and unconfined compression tests have been carried out. Soil samples have been prepared at 5\% rubber particles and it has been investigated time dependent effect of unconfined compression strength for stabilization. As a result, improvement ratio for all time were approximately $20.81 \%-21.48 \%$. It has also been determined that the improvement ratio is the same for all times. In addition, it has been determined that there is no additional increase in the improvement ratio with time depending on the rubber particles.
\end{abstract}

Keywords: soil stabilization, unconfined compression test, rubber particles, time dependent strength

\section{Introduction}

Soil stabilization is a method of improving soil properties by mixing other materials. In other words, soil stabilization refers to the process of changing soil properties to improve strength and durability. There are many techniques for soil stabilization, including compaction and by adding material to the soil. The use of rubber particles in soil stabilization is less common, but worthy of consideration. The use of rubber particles for soil stabilization provides cost effective methods to improve the engineering properties of problematic soils.

Soils stabilized with this material have been extensively tested and do not have any adverse environmental impact. As many of construction is concentrated in populated urban areas, there is increasing need to construct on soft subsoils, which were considered unsuitable for construction. So, stabilization with rubber particles can be used as an important alternative method in the construction of geotechnical substructure on soft subsoils. There are a lot of studies about soil stabilization with addictive materials [1], [2], [3], [4], [5], [6], [7], [8], [9], [10], [11], [12], [13], [14], [15], [17], [18] but there is a limited study about stabilization with rubber particles [16] in the literature.

\section{Material and Methodology}

In this study, serious tests have been conducted in the laboratory to determine the the time-dependent ( 1 hour, 1 day, 7 day) bearing capacity of soil stabilization with rubber particles. Soil samples have been prepared at optimum water content and unconfined pressure tests have been carried out. In the examinations, clay samples which were taken Çukurova region and below the $0.074 \mathrm{~mm}$ screen area were used. Experiments were performed at soil mechanics laboratory of Çukurova University on clay samples.

The liquid limit value of the cohesive material is approximately $42 \%$ and the plastic limit value is approximately $24 \%$ [19]. The grade of the soil was determined as a medium plastisite clay (CI) according to TS
1500 [20]. In the experiments, unconfined compression test machine (Figure 1 - Figure 2) has been used.

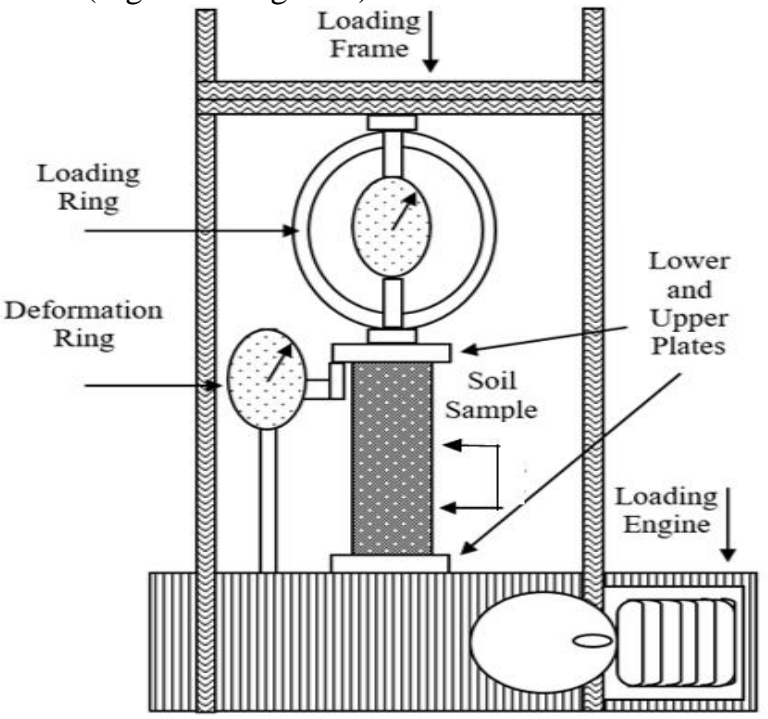

Figure 1: Schematic view of unconfined compression test

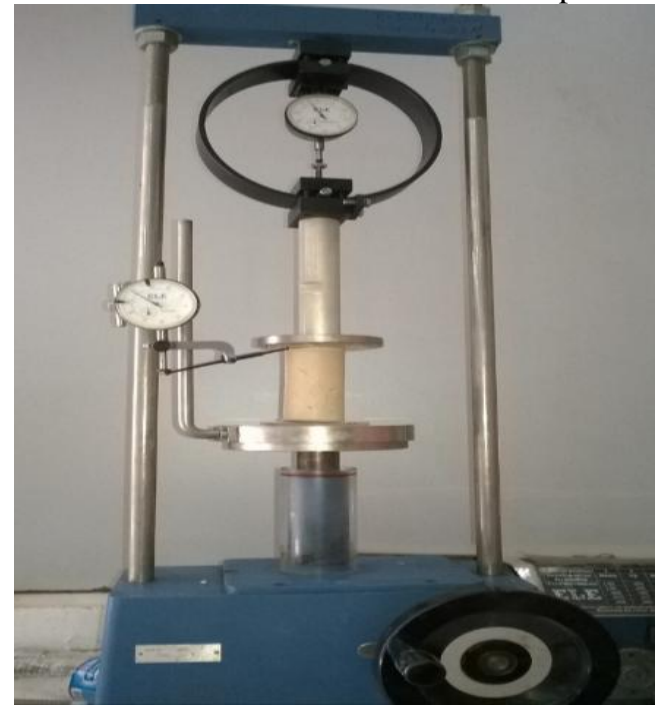

Figure 2: Unconfined compression test machine 


\section{International Journal of Science and Research (IJSR) \\ ISSN (Online): 2319-7064}

Index Copernicus Value (2015): 78.96 | Impact Factor (2015): 6.391

The unconfined compression test is used to measure the shearing resistance of cohesive soils which may be undisturbed or remolded specimens. An axial load is applied using either strain-control or stress-control condition. According to the ASTM standard [21], the unconfined compression strength is defined as the compressed stress at which an independent cylindrical sample of soil will lose out in a basic compression test. On top of it, in this test process, the unconfined compressed strength is afflicted as the maximum load reached per unit area, or the load per unit area at $15 \%$ axial strain, whatever comprises first during the performance of a test [18]. The vertical load has been applyed until the loading decreases on the specimen significantly. When the vertical load have decreased, the strain deformation graph has been drawn by completing the experiment. In order to soils, the undrained shear strength is essential for the definition of the bearing capacity of foundations. The undrained compression strength (qu) of clays is usually determined from an unconfined compression test. The sample has been removed the compression device and has been taked a sample for determining water content [18].

\section{Results and Tables}

In this study, serious tests have been conducted in the laboratory to determine the the time-dependent ( 1 hour, 1 day, 7 day) bearing capacity of soil stabilization with rubber particles. The experimental results have been presented in detail at Figure 3, Figure 4, Figure 5, Figure 6 and Figure 7.

Figure 3 shows the comparison of 1 hour's unconfined compression graphics at the medium plasticity clay soils and medium plasticity clay soils with $5 \%$ of the rubber particles. The 1 hour's unconfined strength for only medium plasticity clay soils $(100 \%$ medium plasticity clay) has been determined $129 \mathrm{kPa}$ [22]. Hence, it has been concluded that when $95 \%$ of medium plasticity clay soil and $5 \%$ of rubber particles, the 1 hour's unconfined compression strength of the mixture increases from $129 \mathrm{kPa}$ up to $152 \mathrm{kPa}$ [23].

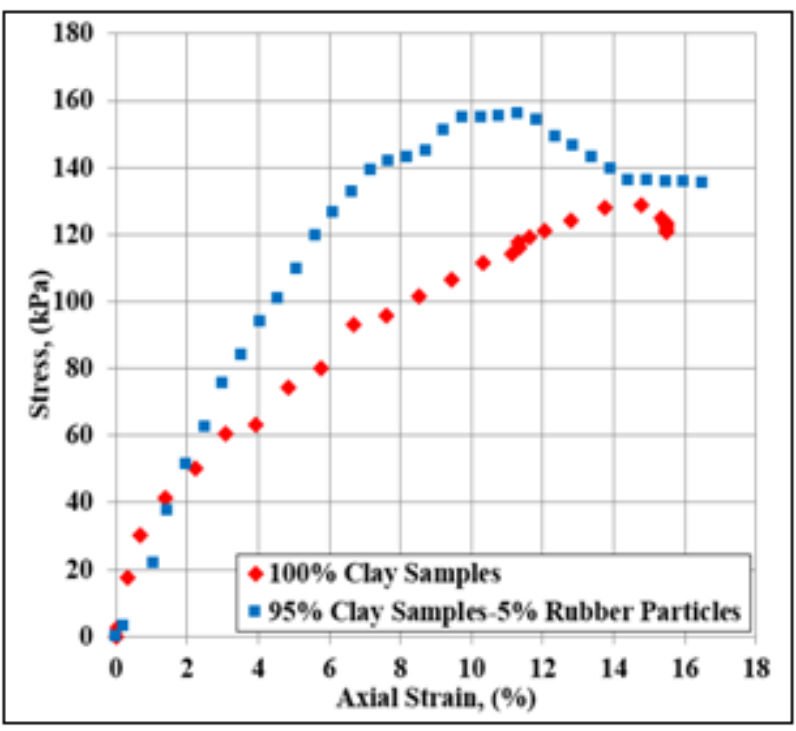

Figure 3: The unconfined compression graphics for 1 hour [20]
Figure 4 shows the comparison of 24 hour's unconfined compression graphics at the medium plasticity clay soils and medium plasticity clay soils with $5 \%$ of the rubber particles. The 1 day's ( 24 hours) unconfined strength for only medium plasticity clay soils (100\% medium plasticity clay) has been determined $135 \mathrm{kPa}$. Hence, it has been concluded that when $95 \%$ of medium plasticity clay soil and $5 \%$ of rubber particles, the 1 day's ( 24 hours) unconfined compression strength of the mixture increases from $135 \mathrm{kPa}$ up to 164 $\mathrm{kPa}$.

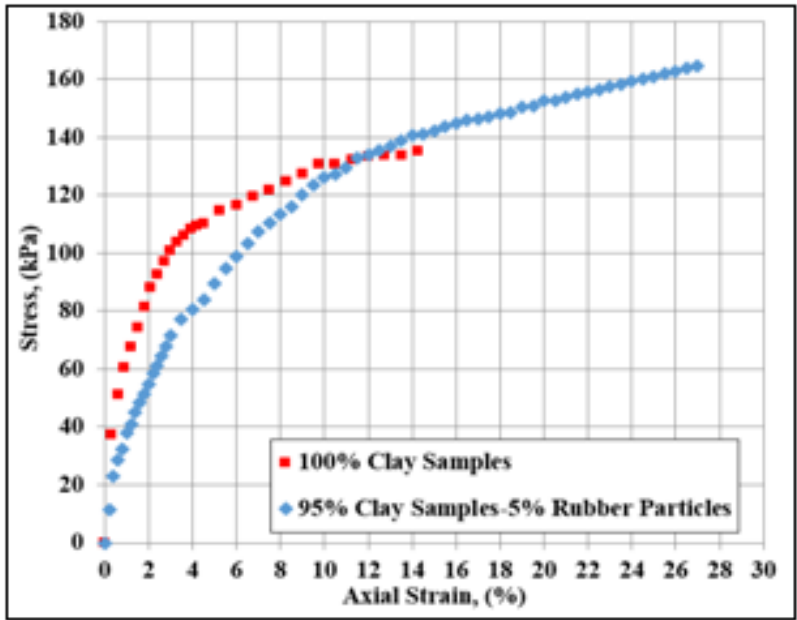

Figure 4: The unconfined compression graphics for 1 day (24 hours)

Figure 5 shows the comparison of 24 hour's unconfined compression graphics at the medium plasticity clay soils and medium plasticity clay soils with $5 \%$ of the rubber particles. The 7 day's (168 hours) unconfined strength for only medium plasticity clay soils ( $100 \%$ medium plasticity clay) has been determined $149 \mathrm{kPa}$. Hence, it has been concluded that when $95 \%$ of medium plasticity clay soil and $5 \%$ of rubber particles, the 7 day's (168 hours) unconfined compression strength of the mixture increases from $149 \mathrm{kPa}$ up to $180 \mathrm{kPa}$.

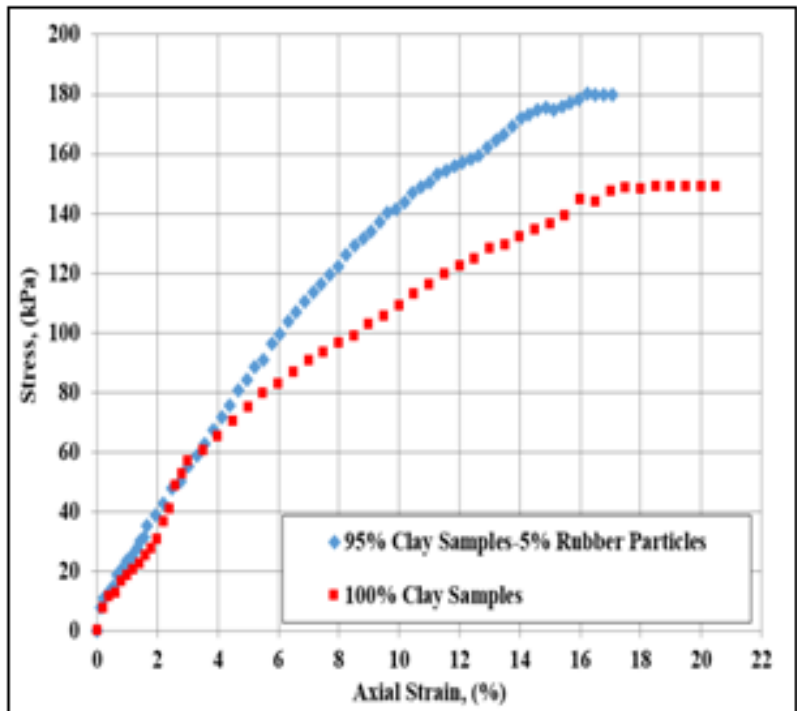

Figure 5: The unconfined compression graphics for 7 day (168 hours) 


\section{International Journal of Science and Research (IJSR) \\ ISSN (Online): 2319-7064}

Index Copernicus Value (2015): 78.96 | Impact Factor (2015): 6.391

Figure 6 shows the comparison of 1 hour's, 1 day's (24 hours) and 7 day's (168 hours) unconfined compression strength at the medium plasticity clay soils and medium plasticity clay soils with $5 \%$ of the rubber particles. From the test results, the unconfined compression strength for 1 hour, 1 day (24 hours) and 7 day (168 hours) have been determined respectively $129 \mathrm{kPa}, 135 \mathrm{kPa}, 149 \mathrm{kPa}$ for $100 \%$ medium plasticity clay and $152 \mathrm{kPa}, 164 \mathrm{kPa}, 180 \mathrm{kPa}$ for $95 \%$ medium plasticity clay soils with $5 \%$ of the rubber particles. It has been determined that there is a considerable increase in the unconfined compression strength compared with medium plasticity clay soil in all time. Depending on the time, $100 \%$ medium plasticity clay sample's strength has increased by around $16 \%$. Similarly, 95\% medium plasticity clay soils with $5 \%$ of the rubber particle's strength occurred an increase of about $15 \%$.

Figure 7 shows the improvement ratio in point of unconfined compression strength at medium plasticity clay soils formed by only medium plasticity clay soils. Improvement ratio for all time have been determined approximately $20.81 \%$ $21.48 \%$. It has also been determined that the improvement ratio is the same for all times. For this reason, it has been determined that there is no additional increase in the improvement ratio with time depending on the rubber particles.

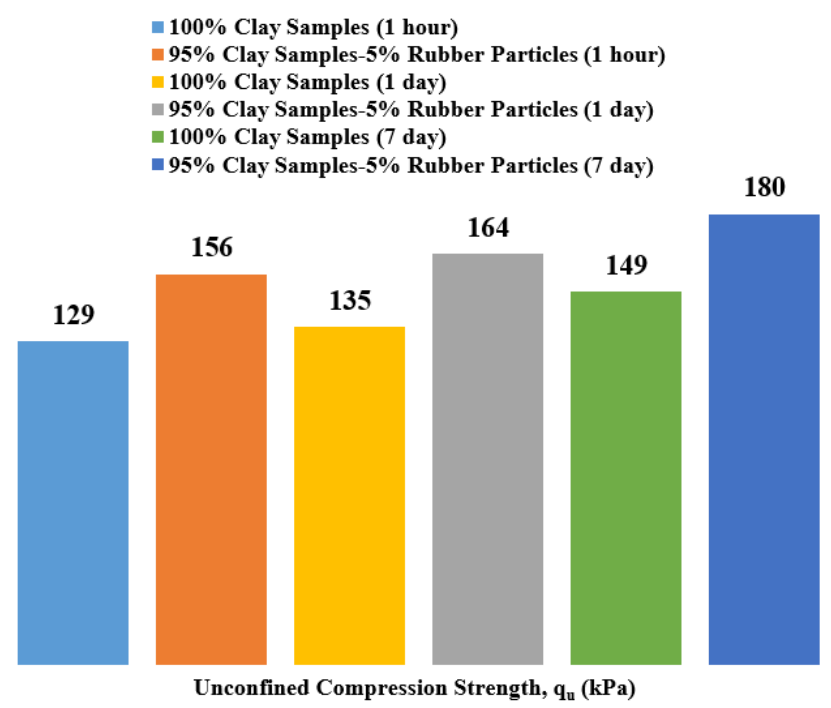

Figure 6: The unconfined compression strength for all times

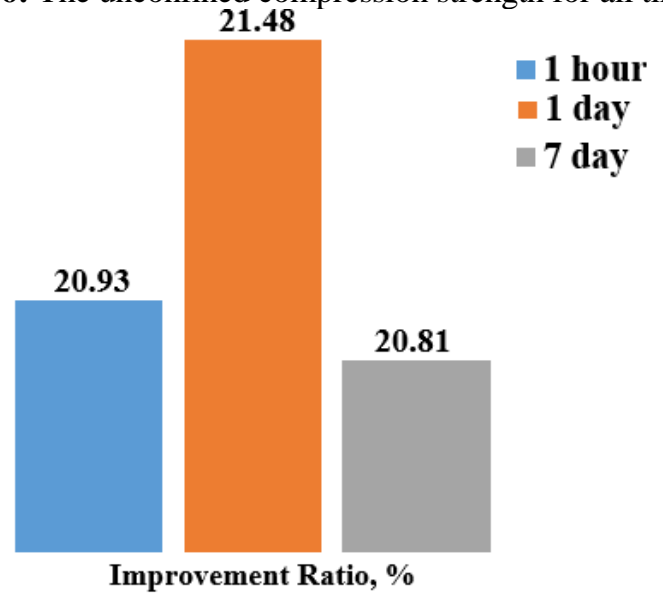

Figure 7: Improvement ratio for all times

\section{Conclusion}

In this study, serious tests have been conducted in the laboratory to determine the the time-dependent bearing capacity of soil stabilization with rubber particles. The experimental results have been presented in detail below.

The unconfined compression strength for 1 hour, 1 day (24 hours) and 7 day (168 hours) have been determined respectively $129 \mathrm{kPa}, 135 \mathrm{kPa}, 149 \mathrm{kPa}$ for $100 \%$ medium plasticity clay and $152 \mathrm{kPa}, 164 \mathrm{kPa}, 180 \mathrm{kPa}$ for $95 \%$ medium plasticity clay soils with $5 \%$ of the rubber particles.

It has been concluded that;

- when $95 \%$ of medium plasticity clay soil and $5 \%$ of rubber particles, the 1 hour's unconfined compression strength of the mixture increases from $129 \mathrm{kPa}$ up to $152 \mathrm{kPa}$ [23],

- when $95 \%$ of medium plasticity clay soil and $5 \%$ of rubber particles, the 1 day's (24 hours) unconfined compression strength of the mixture increases from $135 \mathrm{kPa}$ up to 164 $\mathrm{kPa}$,

- when $95 \%$ of medium plasticity clay soil and $5 \%$ of rubber particles, the 7 day's (168 hours) unconfined compression strength of the mixture increases from $149 \mathrm{kPa}$ up to 180 $\mathrm{kPa}$.

It has been determined that there is a considerable increase in the unconfined compression strength compared with medium plasticity clay soil in all time.

Depending on the time, $100 \%$ medium plasticity clay sample's strength has increased by around $16 \%$. Similarly, $95 \%$ medium plasticity clay soils with $5 \%$ of the rubber particle's strength occurred an increase of about $15 \%$.

Improvement ratio for all time were approximately $20.81 \%$ $21.48 \%$. It has also been determined that the improvement ratio are the same for all times with only $100 \%$ medium plasticity clay sample and $95 \%$ medium plasticity clay soils with $5 \%$ of the rubber particles. For this reason, it has been determined that there is no additional increase in the improvement ratio with time depending on the rubber particles. It has been observed that this rubber particles provide only mechanical improvement.

\section{References}

[1] D. N. Little, "Handbook for stabilisation of pvement sugrades and base course with lime," United States of America Lime association of Texas, 1995. (book style)

[2] J. R. Prusinski and S. Bhattacharja, "Effectiveness of Portland cement and lime in stabilizing clay soils," Transportation Research Record. Issue-1652, pp 215227, 1999. (journal style)

[3] S. Bhattacharja and J. I. Bhatty, "Comparative performance of the Portland cement and lime stabilization of moderate to high plasticity soils," Portland cement association, 2003. (journal style)

[4] J.S., Tingle and R.L., Santori, "Stablisation of clay soils with non traditional additives," National Research Council, Washington D.C., Transportation Research Record No. 1819, 72-84, 2003. (journal style)

Volume 6 Issue 6, June 2017 


\section{International Journal of Science and Research (IJSR) \\ ISSN (Online): 2319-7064}

Index Copernicus Value (2015): 78.96 | Impact Factor (2015): 6.391

[5] M. C. Geiman, G. M. Filz and T. L. Brandon, "Stabilization of Soft Clay Subgrades in Virginia," Phase I Laboratory Study Virginia Transportation Research Council, 2005. (book style)

[6] S. Vitton, "Introduction to soil stabilization," Michigan Technological University, 2006. (book style)

[7] C. Jung and A. Bobet, "Post-Construction Evaluation of Lime-Treated Soils," Indiana Department of Transportation State Office, 2008. (book style)

[8] M. Mirzababaei, S. Yasrobi and A. Al-Rawas, "Effect of polymers on swelling potential of expansive soils," Proceedings of the ICE Ground Improvement 162(3), 111-119, 2009. (conference style)

[9] M. D. Liu, S. Pemberton and B. Indraratna, "A study of the strength of lime treated soft clays," 2010. (journal style)

[10]R. Brooks, F. F. Udoeyo, V. K. Takkalapelli, "Geotechnical properties of problem soils stabilized with fly ash and lime stone dust in Philadelphia," American Society of Civil Engineers, Vol. 23, No. 5, pp. 711-716, 2011. (journal style)

[11]B. Celauro, A. Bevi;acqua, D. L. Bosco and C. Celauro, "Design procedures for soil-lime stabilization for road and railway embankments: Part 1, Review of design methods," Elsevier, 53: 755-764, 2012. (book style)

[12] S. A. A. Khattab and Y. A. Hussein, "The durability of fine grained soils stabilized with lime," Al-Rafidain Engineering 20 (1): 85-92, 2012. (journal style)

[13] A. S. Negi, M. Faizan, D. P. Siddharth and R. Singh, "Soil stabilization using lime," International Journal of Innovative Research in Science, Engineering and Technology, 2 (3): 448-453, 2013. (journal style)

[14] A. Aldaood, M. Bouasker, and M. A. Mukhtar, "Free swell potential of lime-treated gypseous soil," Applied clay science, 102: 93-103, 2014a. (journal style)

[15] A. Aldaood, M. Bouasker, and M. A. Mukhtar, "Geotechnical properties of lime treated gypseous soils," Elsevier, 88-89: 39-48, 2014b. (journal style)

[16]B. Bagriacik, "Ulaşım Yapıları Temel Zeminlerinin Katk1 Maddeleri ile Stabilizasyonu," 1st International Mediterranean Science and Engineering Congress (IMSEC 2016), 4581-4586, 2016. (conference style)

[17]B. Bagriacik, "Ulaşım Yapıları Temel Zemini Iyileştirilmesinde Katkı Malzemesi Seçiminin Önemi," 2 International Congress On Engineering Architecture And Design, 825-826, 2017. (conference style)

[18]Baki Bagriacik, "The Experimental Study on Soil Improvement with Additive Materials on Highways", International Journal of Science and Research (IJSR),6 (6), 2185-2189, 2017. (journal style)

[19] TS 1900-2, İnşaat Mühendisliğinde Zemin Laboratuvar Deneyleri - Bölüm 2: Mekanik Özelliklerin Tayini. (book style)

[20] TS 1500, İnşaat Mühendisliğinde Zeminlerin Sinıflandirılması. (book style)

[21] ASTM D 2166 - Standard Test Method for Unconfined Compressive Strength of Cohesive Soil. (book style)

\section{Author Profile}

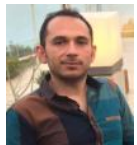

Baki Bagriacik entered Cukurova University Faculty of Engineering and Architecture Department of Civil Engineering in 2004. In 2008, he graduated from the Faculty of Engineering and Architecture and the Department of Civil Engineering as the first. 30th anniversary of the establishment of the Faculty of Engineering and Architecture held at Cukurova University in celebration of the project and a final assignment in the competition won the first Civil Engineering and Engineering Faculty of Architecture eligible to receive awards as the latter. In addition, it is entitled to receive certificates and awards from different institutions and organizations. In 2010, he completed his master's degree in Civil Engineering Department of Cukurova University Institute of Science and was awarded the title of "High Engineer" and received scholarship support by TUBITAK during his master's degree. In 2015, he completed his Ph.D. in Civil Engineering Department of Cukurova University Institute of Science and was awarded the title of "Doctor" and received scholarship support by TUBITAK during his Ph.D. He is still working as a physician teaching staff at Cukurova University Faculty of Engineering and Architecture Department of Civil Engineering. There are many publications, notifications, awards and citations in his field of specialization in various national and international journals and symposia. 